Boross Klára és Tóth Gábor a régi nyomtatványok világába kalauzol bennünket. Nem véletlenül a legjelentősebb magyar gyüjtemények között tartja számon a szakma, hiszen ez az elsőrangú kollekció mindig is kedvelt területe volt a humán kutatásoknak. A szerzők bemutatják a legjelentősebb adományozókat (Teleki és a Batthyány család, Ráth György, Kresznerics Ferenc, Vigyázó Ferenc) és pontos jellemzést adnak a könyvgyüjtemény nyelvi és tartalmi megoszlásáról. Ha a külföldi látogatók megkérdezik - és ezt nagyon szeretik megkérdezni -, melyik a legrégibb nyomtatványa az Akadémiának, a könyvtárosok büszkén vághatják rá, hogy a 42 soros Biblia töredéke, melyet 1921-ben kaptak ajándékként. A jól ismert ősnyomtatványok mellett (elég itt utalni Rozsondai Marianne és Rozsondai Béla 2013-as nagyszerü katalógusára) említsük meg a Johannes Alexander Brassicanus számára összekötött Dürer-kötetet, Gyulaffy Lestár versgyüjteményét (Pietro Gherardi, In foedus et victoriam contra Turcas ... poëmata), Dobai Székely Sámuel Heltai-krónikáját, Jankovich Miklós és Toldy Ferenc jegyzeteivel kiegészített Ilosvai Selymes Péter-históriát, Prágay András Guevara-fordítását a I. Rákóczi Györgynek (a későbbi fejedelemnek) szóló dedikációjával és a kivégzett Nádasdy Ferenc tulajdonosi bejegyzését.

Kelecsényi Ágnes és Dévényi Kinga az 1951-ben megnyíló Keleti Gyüjteményt mutatja be a bibliofileknek. A kollekció alapításában kiemelkedő szerepe volt Ligeti Lajosnak és Rásonyi Lászlónak. A legváltozatosabb hordozóanyagokon öriznek elképesztően sokszínü könyvtári dokumentumokat: nyomódúcok, illusztrált fanyomatok papíron, szerencsehozó amulettek, tibeti kották, héber, török és perzsa kódexek, Stein Aurél fotói, fakéregre írt jóskönyvek, kínai selyemkönyvek, örmény kéziratok és természetesen a már említett Ibrahim Müteferrika-nyomtatványok és a Csoma-hagyaték sorakoznak egymás után.

Isztray Simon a törzsgyüjteménybe, Hay Diana az Akadémiai Levéltárba kalauzol bennünket. Számos könyvészeti ritkaságra bukkanhatunk a törzsgyüjteményben is: megemlíthetjük a Panzer-, valamint a Hanh-féle rovarokkal és pókokkal foglalkozó kötetek színezett metszeteit, Boilly humoros képeit, illetve a William Turner rajzai alapján készült 1830-as nyomtatványt. A kutatók számára kiemelkedően fontosak a levéltárban található fondok: nevezetesen a Magyar Tudományos Tanács anyaga, az Akadémia elnökeinek, fötitkárainak és más vezetőinek iratai, illetve a Titkárság - régebben: az Akadémia Központi Hivatala - iratai. A reprodukciók között megtaláljuk a Nobel-díjas Hevesy György és Szent-Györgyi Albert magyar nyelvű leveleit is.

Jól látható tehát, hogy még mindig fontosak számunkra a különleges gyüjtemények: a különgyüjtemények. Továbbra is nélkülözhetetlenek a kincseket örzö könyvtárosok, akiknek egyaránt otthon kell lenniük szakmájuk tudományos életében és a ritkaságokat bemutató ismeretterjesztésben. És szükség van ránk, olvasókra is. Végezetül - A bor filozófiája szelleméhez híven - a Calliotheca olvasásához-forgatásához egy palack szekszárdi vörös dukál. A bibliofil kiadványt Horányi Károly állította össze, Krähling Edit szerkesztette, munkatársa volt (a már említettek mellett) Mázi Béla. A reprodukciók elkészítésében részt vett Láng Klára.

FARKAS GÁBOR FARKAS

\title{
Riccarda Suitner, Die philosophischen Totengespräche der Frühaufklärung, Hamburg, Felix Meiner Verlag, 2017 (Studien zum achtzehnten Jahrhundert, 37). 276 p.
}

A fiatal olasz kutató, Riccarda Suitner könyvét olvasva egy izgalmas irodalmi nyomozás részesei lehetünk. A nyomozás tárgya egy felvilágosodás kori szövegegyüttes, az 1729 és 1734 között megjelent, német nyelvü filozofikus halotti párbeszédek (,philosophischen Totengespräche”), amelyek a kutató hipotézise szerint egy összefüggő, koherens szövegegységet alkotnak. A felvilágoso-

DOI $10.17167 / \mathrm{mksz} .2020 .1 .78-80$ 
dás és a heterodox áramlatok eszmetörténete iránt elkötelezett Martin Mulsow tanítványa nehéz feladatra vállalkozott. A feltárni szándékozott szövegkorpusz keletkezési körülményeiben ugyanis jóval több az ismeretlen, mint az ismert elem.

A Lukiánosztól eredeztethető halotti párbeszéd a 18. század elejének nagyon népszerủ irodalmi múfaja volt, ekkor élte virágkorát. Míg a 17. században a humanizmus által újra felfedezett müfaj még teljes mértékben Lukiánosz formai modelljét követte, a felvilágosodás korára egyre inkább vitairodalommá formálódott, a közérdeklődésre számot tartó, érzékeny kérdések kockázatok nélküli megszólaltatására adott módot, később pedig privilegizált politikai propagandaeszközzé vált.

A nyomozás legnagyobb nehézségét az jelenti, hogy a röplapirodalom más müfajaihoz hasonlóan a halotti párbeszédek szerzői, kiadói és illusztrátorai névtelenül vagy álnéven publikáltak. A művek megírásának hátterében legtöbbször személyes konfliktusok, intellektuális társaságok, mesterek és tanítványok közti rivalizálás, és nem utolsó sorban gazdasági érdekek húzódtak meg. Alkalmi jellegükből adódóan a halotti párbeszédek nem hosszú távú megőrzésre íródtak, sokkal inkább aktuális igényeket kívántak kielégíteni, és abból valamiféle gyors hasznot húzni. Általában véve provokatív témájuk és meghökkentő személytársításaik okán (pl. egy II. Frigyes porosz uralkodó által írt halotti párbeszéd Szüz Máriát és Madame de Pompadourt helyezi egymással szembe) garantált jövedelmet biztosítottak. Mivel a müfaj regionális elterjedtséget mutat, és olyan egyetemek vonzáskörzetében jelentkezett, mint Halle, Lipcse és Jena, a fellelhető példányok is leginkább a közép-németországi könyvtárakban találhatóak szétszóródva, különböző más jellegü szövegekkel egybekötve. Az elemzett filozofikus halotti párbeszédeket (amelyek egyáltalán ismertek voltak) David Fassmannak tulajdonította a szakirodalom, a halotti párbeszéd müfaját népszerüsítö, $G e-$ spräche im Reiche der Toten címmel havi rendszerességgel megjelentetett kiadványai miatt. Suitner egyik kiemelt célja ezért annak bizonyítása volt, hogy nem megalapozott a szakirodalomnak a szerzőséget illető feltételezése.

A filozofikus halotti párbeszédek megírásának apropóját minden esetben a dialógus egyik főszereplőjének halála jelentette, aki mellé egy már korábban elhunyt közismert személyt választottak partnerül a fiktív, holtak birodalmában lejátszódó beszélgetéshez. A cél többek között az éppen elhalálozott személy előtt való tisztelgés, életrajzának és érdemeinek megismertetése volt. A beszélgetések résztvevői a 18. sz. elejének, illetve az előző generációnak prominens gondolkodói, teológusai, illetve filozófusai voltak, olyanok, mint Christian Thomasius és August Hermann Francke, René Descartes és Andreas Rüdiger, Nikolaus Hiernonymus Gundling és Johann Franz Budde, Johann Friedrich Mayer és Johann Wilhelm Petersen, Balthasar Bekker és Christian Scriver valamint Gottfried Wilhelm Leibniz.

A fillozofikus halotti párbeszéd az átlagosnál mủveltebb olvasót kívánt meg, aki olyan utalásokat is értett, amelyek nem közismert müvekből, hanem magas színvonalú, esetleg tiltott irodalomból származtak. Ki kellett ismernie magát nemcsak az ókori és modern filozófiában, hanem a legfelsőbb körök disputáiban is (általában a pietistáknak és a velük szemben álló irányok képviselőinek vitájában. Ebben úgy tünik az erdélyi báró Lázár János is jártas volt, akitől egy versrészletet is idéz a szerző.).

A könyv a bevezető és az első, műfajtörténettel foglalkozó fejezet után 7 fejezetben tárgyalja a filozofikus halotti párbeszédeket. Mindegyik fejezet egy-egy megtalált párbeszédet elemez, a születési és terjedési kontextus egy bizonyos aspektusának elmélyítésével. Ezek az aspektusok (pl. müfaji átfedések, kiadók közti konkurenciaharcok, a rézmetszők müködése stb.) a többi dialógus esetében is jelen vannak, de az adott dialógus esetében hangsúlyozottabban nyilvánulnak meg. A könyv közepén egy címlapokat, rézmetszeteket, versrészleteket tartalmazó képmelléklet segíti az olvasót a formai jegyek, illusztrációk, szimbólumok megismerésében. Nem csupán a hosszú bibliográfiából, hanem a lábjegyzetekből és az elemzésekből is kitünik a szakirodalom nagyon alapos ismerete. 
A nyomozásban csupán olyan mellékesnek tünő jegyek segítenek, mint az oldalszámozás, pecsét, kötés, és a különböző példányok közti eltérések, a címlapillusztráció, a rézmetszetek szimbólumai és monogramjai. A sok név és a szétágazó szálak követése nem kis kihívás az olvasónak. Ennek a nehézségnek azonban úgy tủnik a szerző is tudatában van, és módszeresen vezeti az olvasót, többnyire az egyes alfejezetek, egységek végén.

Bár nem lehetséges teljes bizonyossággal megállapítani egyetlen halotti párbeszéd szerzőségét, kiadóját sem, legfeljebb a kiadás évszáma és egyes rézmetszők neve derül ki egyértelmüen, a nyomozás mégis számos, a szerzőség megállapításánál fontosabb eredményre vezet. A kutakodás közben ugyanis feltárul az a félig hivatalos és félig titkos egyetemi világ („,subakademische milieu”), amelyben az adott írások születtek, a szociális és földrajzi kontextus, a 18. század eleji publicisztika gazdasági dinamikája, és megrajzolható egy viszonylag precíz olvasói profil. A szerzők és rézmetszők, kiadók utáni kutatás közben megismerhetjük a felvilágosodás korát leginkább foglalkoztató vitakérdéseket, az illusztrátorok, rézmetszők világát, a pietizmus és a különböző divatossá váló új filozófiai eszmék harcát, a könyvpiac korabeli működését, a kalózkiadványokat és a kiadók, szerzők közti plagizálási és konkurenciaharcot. Merthogy a filozofikus halotti párbeszédek sok fronton vitát gerjesztettek, nem csupán filozófiai, hanem teológiai, gazdasági és személyes téren. Olyan témákkal foglalkoztak, mint pl. az apokatasztázis és chiliazmus, a lélek és a test viszonya, kínai filozófia, kabbala, matematika és filozófia, teológia, valamint exegézis közti kapcsolat, ókori és modern ateizmus, démonológia, és olyan filozófiai rendszerek, amelyek elsősorban Christan Wolf, Descartes és Leibniz nevéhez kötődtek. A szövegek gazdagok intertextuális utalásokban, és a háttérben észlelhető a heterodoxia és a 'literature clandestine' irodalmának hatása (lásd pl. Spinoza vagy Martin Seidel Origo et fundamenta religionis christianae-jának értékelését).

A bemutatott könyv egy bizonyíték kíván lenni arra, hogy a nyilvános, legális kiadványok és a tiltott irodalom között létezett egy ún. félhivatalos, köztes szintje is a kommunikációnak. Ennek a kultúrharc formáját öltő kommunikációnak egyik közkedvelt föszereplője volt a halotti párbeszéd, egy olyan polemikus múfaj, amely jelentősen befolyásolta a felvilágosodás sorsát, eredményeit.

Riccarda Suitner könyvét mindenképpen ajánlom azoknak, akik a 18. századi filozófia és publicisztika iránt érdeklődnek, valamint a pietizmusnak és a heterodox áramlatoknak a felvilágosodásban jelentkező hatását kutatják.

ÚJLAKI-NAGY RÉKA

Géza Pálffy, Die Krönungsfahnen in der Esterházy Schatzkammer auf Burg Forchtenstein, Die Geschichte der Krönungsfahnen der Länder der Stephanskrone vom Spätmittelalter bis Anfang des 20. Jahrhunderts, Eisenstadt, 2018 (Mitteilungen aus der Sammlung Privatstiftung Esterhazy, 10).

Sok tekintetben különleges az a kiadvány, amely Pálffy Géza, a Szent Korona Kutatócsoport vezetője tollából született meg néhány hónappal korábban. Pedig a téma első ránézésre nem lehet meglepetés szakmai berkekben, hiszen a szerzö több éve foglalkozik a magyar királykoronázások alkalmával használt zászlók történetével. Ismeretes a fraknói várban található Esterházy-gyüjteményben tett felfedezése a legkorábbi ilyen alkalomból készült tárgyakkal kapcsolatban, és magáról a koronázásokról, illetve a Szent Koronáról is számos alapmüvet tett le az asztalra a magyar és a nemzetközi tudományos közegben egyaránt. Ezzel együtt ez a kötet több szempontból elüt a megszokottól, és mivel mindez elgondolkodtató tanulságokkal jár, most ezeken a sajátosságokon keresztül méltatnám a kiadványt.

Elsőként a könyv szerkezete hökkentheti meg az olvasót. Az első - és egyben nagyobbik - felét a Magyar Királyság országainak szimbólumai, ezen belül különösen a koronázási zászlók, és a Fraknón

DOI $10.17167 / \mathrm{mksz} .2020 .1 .80-82$ 